\title{
The Effect of Benefits Offered and Customer Experience on Re-use Intention of Mobile Banking through Customer Satisfaction and Trust
}

\author{
Defni Febrian ${ }^{1 *}$, Megawati Simanjuntak², Nur Hasanah ${ }^{3}$ \\ 1,3 School of Business, IPB University, Indonesia \\ ${ }^{2}$ Department of Family and Consumer Sciences, Faculty of Human Ecology, IPB University \\ *Corresponding Author: defnifeb@gmail.com
}

\begin{abstract}
This study analyzes the effect of benefits offered and customer experience on the re-use of mobile banking through customer satisfaction and trust as mediating variables. This study involved 280 respondents who were selected by purposive sampling technique with predetermined criteria. Data were collected through a questionnaire distributed online. The analysis used is Structural Equation Modeling with LISREL version 8.80. The results show that benefits offered and customer experience have a significant effect on satisfaction. Satisfaction has a significant impact on trust and re-use intention, and trust significantly affects re-use intention. The managerial implication that can be implemented in the company is to maintain deeper Islamic features and social, collaborate with fintech, Improved network quality, and capacity, and continue to innovate mobile banking features.
\end{abstract}

Keywords: benefit offered; customer experience; customer satisfaction; mobile banking; re-use intention

\section{INTRODUCTION}

Technological transformation has an impact on changes in business transformation through the industrial revolution, which is currently in the era of 4.0 (internet era). In this era, the use of digital technology has become commonplace. In the midst of the digital disruption era, all industries continue to invest and innovate to carry out digital development, including banking.

In addition to technological transformation, currently, companies are faced with the COVID-19 Pandemic, which has a significant impact on the global economy. Low investment sentiment will lead the economy in a negative direction (Nasution et al. 2020). Various policies were implemented to overcome the spread of COVID-19, such as physical distancing, wearing masks to Large-Scale Social Restrictions (PSBB). As a result, there has been a decrease in human activity, layoffs, a decrease in imports and exports, an increase in prices (inflation), as well as losses in the tourism sector and its derivatives 
(Yamali and Putri. 2020). COVID-19 has also changed the pattern of human interaction that previously interacting face to face turned into digital. This certainly has an impact on businesses, including banking, so that customer visits to branches have decreased since the Pandemic, and the need for digital transactions via mobile banking is an option. It negatively impacts banks if they cannot increase customer satisfaction and trust in their mobile banking.

With the technological transformation, behavior change, and the COVID-19 pandemic disaster, companies must quickly make innovations, change strategies, increase promotion cost efficiency, and delay large investments. However, one thing cannot be stopped during the current Pandemic, namely digital investment and innovation, mobile banking. This is because mobile banking has become the backbone of the business, which is still growing and massive. Mobile banking is the newest service after internet banking, with the development of mobile technology, providing banking services via smartphone devices, smartphone operators, and banks. Previously had no business relationship, now has become an alliance partner both of which have benefits offered ease of use and security. Thus, mobile banking has brought about a fundamental change in the types of banking services (Lee et al., 2015).

Several factors influence a person's interest in using mobile banking, including transactions, security, experience, trust, saving time and effort, price, quality of products and services, and customer satisfaction (Sagib and Zapan 2014). The benefits offered have a positive and significant impact on the use of mobile banking. This result is supported by Sampaio et al. (2017), Samudro et al. (2020), and (Susanti et al. 2019a) that found a positive relationship between the benefits offered and customer satisfaction. In addition, three satisfaction consequences need to be analyzed, namely trust, customer loyalty, and positive word-of-mouth. Another research conducted by Kristianti and Prambudi (2015) found that benefits offered by mobile banking applications, especially at the level of security, positively affect customer satisfaction for students in DKI Jakarta.

The following marketing concept provides a unique experience to customers, which is known as the customer experience. This concept seeks to present unique, positive, and memorable experiences to consumers to build lasting relationships with consumers and positively influence consumer satisfaction. Customer experience divides experiences into five dimensions, namely sense, feel, think, act, and relate, which are the keys to shaping customer satisfaction while using a product. Customer experience can stimulate customer motivation, thereby increasing the value of products and services. A positive customer experience can encourage the creation of an emotional connection between the company brand and the customer. Simanjuntak et al. (2020) and Fikri et al. (2019) emotional play an important role in determining the customer re-purchase intention. In addition, Mulyono and Djatmiko (2018) explained that customer experience would increase customer loyalty due they are satisfied by the company's performance. Furthermore, customer experience in electronic banking, especially in terms of ease of access, ease of use, trust, and usability, will have a positive effect on customer satisfaction (Liébana-Cabanillas et al. 2016)

Other studies also significantly affect the five dimensions of customer experience on student satisfaction with android smartphone users (Mantala and Firdaus 2016). When the customer experience is good, it will form a harmonious relationship between service providers and consumers, creating satisfaction. In addition, customer expectations also have a significant effect on post-purchase from evaluating experiences in customer 
experiences (Verhoef et al., 2009). Customer expectations are in accordance with expectations so that customers will feel satisfied and get an experience that will make customers buyback. Customer experience in mobile commerce services such as timesaving and convenience in purchasing goods wherever they are located will have a significant effect on customer satisfaction because customers will find their activities helped (Kalinić et al. 2020)

Customer satisfaction is an indicator of sales behavior, both goods, and services. Research conducted by Sidharta and Suzanto (2015) states that good customer satisfaction will increase the transaction process and consumer trust. When a company offers a good quality product/service, it tries to maximize the transaction and offer a lower price. This makes customers more likely to feel trust, which in turn increases customer loyalty. If the quality of service is not good, the transaction is not maximal, and the price is higher, and if there is something that is not good, the customer will feel dissatisfied (Bua. 2009). Good satisfaction is a superior strategy that will have a positive effect on trust which will ultimately increase customer retention (Ranaweera and Prabhu 2003; (Susanti et al. 2019b)

The path of trust goes through a long process. If trust has arisen between the customer and the company, it will be easier to establish good relationships with customers. Customer trust can make customers come back to make repeat purchases (Yuliati et al. 2020). With customer satisfaction, trust will be created in the minds of customers. Danesh et al. (2012) command in their research that every company has a goal to develop customer trust through customer satisfaction. Companies can maintain their customers for a long time. The results of these studies indicate that customer satisfaction has a significant effect on customer trust.

Customers who have good satisfaction and trust, in the end, make the customer make use or re-purchase. This is in accordance with the research of Saidani et al.(2019); satisfied customers will generate interest to re-purchase because they see it from the right side. Therefore, this study was conducted because it complements existing research.

This research is essential to analyze the re-use of mobile banking, which is currently the backbone of banks to continue to grow in the midst of a pandemic. In addition, mobile banking is the answer to technological changes and to anticipate competitors, such as banking, e-commerce, and financial technology (fintech), which are aggressively developing digitally. Bank Syariah Indonesia's mobile banking active user customers are only $9 \%$ of the total 15 million customers; this is a concern to increase active users. The more active users it will increase the bank's fee base, which increases the company's profit. Active mobile banking users are customers who use mobile banking for transactions at least once a month. Based on the explanation above, it is interesting to conduct research related to the effect of benefits offered and customer experience on the re-use of mobile banking through customer satisfaction and trust. This research is expected to provide alternative strategies for developing and improving company policies, especially those related to the benefits offer and customer experience of mobile banking, to increase the number of active mobile banking users. 


\section{HYPOTHESES DEVELOPMENT}

\section{Benefit Offered}

The benefit offered is the ease of use offered in relation to applications for mobile banking, such as the ease of navigating interactions with banks (Casaló et al. 2008). Benefits offered, according to Kim et al.(2003) measured through time-saving indicators. Time-saving can be seen from the duration of time when using the mobile banking application for each transaction. According to Hayashi and Toh (2020), the benefits offered are faster payment services through access to mobile banking, internet banking, and physical bank branch offices. Of all these benefits, mobile banking provides the most benefit of faster payments. Tiana et al.(2019) suggest that the benefits offered to mobile banking include: transaction security, safe use at any time, guaranteed information secrets, application system security, service reliability, ease of use of applications, ease of understanding the application menu, ease of downloading applications, operational systems, and savings time.

\section{Customer Experience}

The customer experience comes from a set of relationships between a customer and an item or service, a company, or part of its company, which cause a response (Nasermoadeli et al., 2013). Consumer experience is a growing priority in marketing research because consumer experience determines consumers' quality in competitive competition. The consumer experience has a different concept from service quality because it requires appropriate measurement. Rini (2019) argues that consumer experience involves the five senses, heart, mind, which can place the purchase of a product or service between the larger contexts of life. Customer experience is the creation of consumer satisfaction through experience. Therefore, customer experience is about understanding the consumer's lifestyle and broadening the marketer's view from the product to the consumption process. Evaluation of consumer experiences depends on the comparison between consumer expectations and company performance.

\section{Satisfaction}

Norhermaya and Soesanto (2016) state that satisfaction is a feeling of pleasure or disappointment in someone who arises after comparing the product's perceived performance (or results) against expectations. If the performance fails to meet expectations, the customer will not be satisfied, and vice versa, if the performance is in line with expectations, the customer will be satisfied. The factors that influence customer satisfaction consist of service availability, the responsiveness of service, timeliness of service, and overall satisfaction with service. Oliver and DeSarbo (1988) state that they refer to vendor assessments. Meanwhile, Hult et al. (2019) said that satisfaction is a customer assessment based on experiences that involve emotional judgments. Satisfaction is an effective response from customers to re-use mobile banking (Püschel et al. 2010).

\section{Trust}

Trust in general can be interpreted as a feeling that someone has to trust another party because that party can provide something according to what is expected and has high integrity if it is associated with quality. Among these qualities are consistency, competence, honesty, fairness, responsibility, being very helpful, and kind/benevolent. This quality maintains long-term relationships with customers or users of mobile banking applications; the bank needs a concept to increase customer satisfaction (Arwani et al., 2011). 
Trust has direct and indirect effects on consumer purchasing decisions and also has a long-term impact on consumer loyalty through satisfaction (Kim et al., 2009). This definition provides an explanation that trust is a fundamental component of a marketing strategy in creating true relationships with consumers. Banking companies operating in the service sector build cooperative relationships with their customers as a competitive strategy.

\section{Re-use intention}

The intention to re-use (re-use intention) of a system or technology can be influenced by a strong belief in the use of technology. The intention to re-use a technology leads to the user's purpose in carrying out its activities and can be considered a reason for their beliefs and behavior. These behaviors can be based on positive or negative feelings (Ajzen. 1991). It can be assumed that if a person has high intentions, the effect on behavior will also be high.

\section{Relationship between Benefit Offered and Satisfaction}

The research by Tiana et al. (2019) showed that the benefit offered consists of ten indicators, i.e., banking, security of use in the mobile banking application at all times, confidential information is guaranteed, protection of the mobile banking application system, reliability of mobile banking application services, ease of use of mobile banking applications, ease of understanding the menu, mobile banking application, easy downloading of a mobile banking application, operational system, and saving time. The variable benefits offered to describe the mobile banking application through security and ease of use. This shows that a useful application will provide satisfaction to its users; thus, the benefits of the product obtained in its use will affect the level of customer satisfaction of the bank customers using the mobile banking application. The research conducted by Benedicktus et al. (2010) states that the benefits offered in online retail purchases can lead to satisfaction.

The research results conducted by Prayoga et al.(2015) stated that confidence has a positive and significant effect on customer satisfaction. The use of mobile banking on smartphones has the benefit of making it easier for customers to meet their financial needs and is directly related to customer satisfaction (Tran and Corner 2016). This means that the confidence benefits, which include company reputation, employee reliability, the accuracy of company promises, and trust in workshop employees, have made customers satisfied.

\section{$\mathrm{H}_{1}$ : Benefit offered has a positive effect on satisfaction}

\section{Relationship between Customer Experience and Satisfaction}

Research by Mantala and Firdaus (2016) states that the customer experience variable positively affects satisfaction and plays a role in shaping consumer perceptions of the product. These results indicate that the better the consumer experience resulting from using a service or product, the higher customer satisfaction will be. Customer experience in using m-commerce daily through their mobile devices will affect customer satisfaction and recommend services to others. In line with previous research, Giannakos (et al. 2011) revealed that customer satisfaction obtained from previous purchase experiences would increase confidence to recommend the product to others.

Salim and Catherine (2013) state that customer experience has a significant effect on customer satisfaction. This means that the higher the customer experience established by 
the company, the higher customer satisfaction will be. In other words, customer satisfaction can be formed by the presence of customer experience. The results of this study are in line with the research of Vivie et al.(2013) stated that there is a strong positive direct influence between the dimensions of customer experience quality, namely accessibility, competence, helpfulness, personalization, and value for time on customer satisfaction. Zhou et al. (2007) also confirmed that there is a positive relationship between customer experience and online shopping satisfaction and increasing the number of purchases

$\mathrm{H}_{2}$ : Customer experience has a positive effect on satisfaction

\section{Relationship between Satisfaction and Trust}

Based on research conducted by Walter et al.(2000), customer satisfaction significantly affects customer trust. Customer satisfaction is an attitude based on a customer's experience that supports the trust felt by customers in the company. Customers believe in the honesty and ability of the company to meet customer needs and demands. If the customer is satisfied, then the trust in the company will grow. This is in line with Madjid's (2013) research that customer satisfaction significantly affects customer trust. This study has proven that better customer satisfaction will increase customer confidence to keep buying goods. Furthermore, McCole et al. (2019) confirmed that customer satisfaction would affect trust and continuance intention. However, building satisfaction, especially in online purchases, is not easy and quite challenging.

\section{$\mathrm{H}_{3}$ : Satisfaction has a positive effect on trust}

\section{Relationship between Trust and Re-use intention}

The high trustworthiness of the product influences the intention to re-use. The higher the instilled trust will result in high re-use too (Liu \& Tang. 2018). Nangi and Sukaatmadja (2015) have conducted research related to the relationship between trust and re-use intention. The result is that trust has a positive and significant effect on interest in purchasing or re-using electronic commerce. In line with the research of Giantari et al.(2013), trust has a positive and significant effect on consumer intention to re-use. According to Astarina et al.(2017), the role of trust as a mediating variable can be a perfect mediator that positively influences online purchase intentions.

\section{$\mathrm{H}_{4}$ : Trust has a positive effect on re-use intention}

\section{Relationship between Satisfaction and Re-use Intention}

Satisfaction is a measurement of product sales success because good satisfaction will make customers intend to re-purchase (Y. H. Fang et al., 2011). Research conducted by Ebrahimi and Tootoonkavan (2014), Samudro et al. (2019), Pebriani et al. (2018), Adzhani et al. (2021), and Arief et al. (2019) showed that perceived customer satisfaction would affect re-purchase intention and recommend others. Supported by Dholakia and Zhao (2010), the correlation between satisfaction and re-use intention is very high. Another study also conducted by He et al. (2008) informs that high customer satisfaction will increase re-purchase intention. In the end, it will help increase the company's future profitability through promotions or discounts. Theoretically, these findings are in line with previous research, which according to Nilsson and Wall (2017), shows a positive relationship between satisfaction and the desire to buy back. 
$\mathrm{H}_{5}$ : Satisfaction has a positive effect on re-use intention

Based on the hypotheses that developed, a framework of the research is as follows in Figure 1.

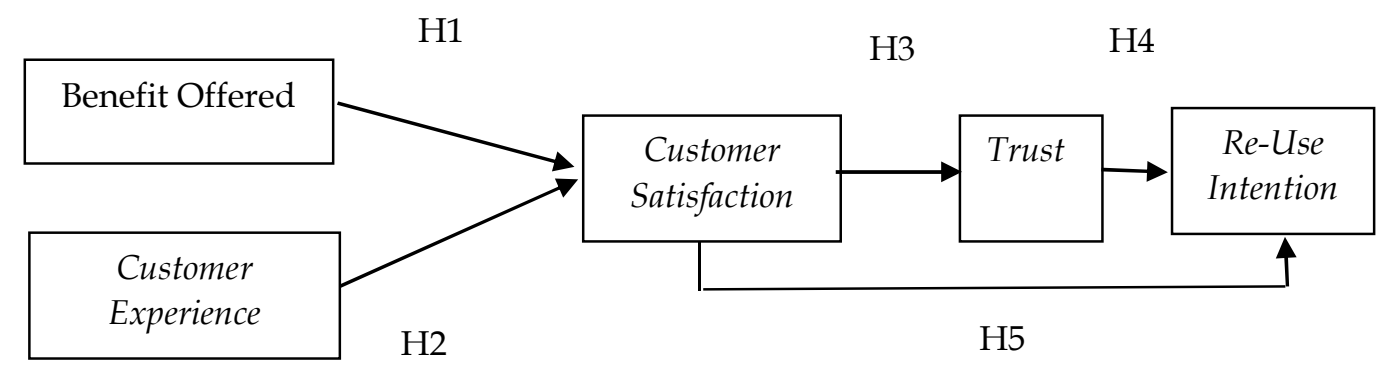

Figure 1. Research Framework

\section{METHOD, DATA, AND ANALYSIS}

This research is conducted in all PT Bank Syariah Indonesia Tbk. (BSI) work areas throughout Indonesia. The selection of BSI customers is the object of research because it is interesting where BSI is currently the largest Islamic bank in Indonesia which has just merged. In addition, there is a gap in BSI mobile banking active users, which is only nine percent of the total customers; this is a challenge for BSI to increase the number of active users in the digital era and during the Pandemic. The sampling technique used was nonprobability sampling, sample criteria in this study are respondents who have become BSI mobile banking customers. The number of respondents obtained in this study was 284 respondents; there were four respondents who were not included because they did not match the research criteria. Therefore, the number of respondents who met the criteria for analysis was 280 respondents. This study uses primary data obtained from respondents related to research variables. The instrument used to obtain promotional data was an online questionnaire created using Google Form.

The measurement of variables in this research is as follows in table 1.

Table 1. Variable and indicator of research

\begin{tabular}{ll}
\hline \multicolumn{1}{c}{ Variable } & \multicolumn{1}{c}{ Indicator } \\
\hline Benefit Offered & $\begin{array}{l}\text { Security, complete features, reliability, convenience, save time } \\
\text { Customer experience }\end{array}$ \\
Satisfaction & $\begin{array}{l}\text { Good product quality and service, good relationship, fair } \\
\text { treatment, a good performance in general, helpfulness }\end{array}$ \\
Trust & $\begin{array}{l}\text { Honest and sincere, fulfilling promises, transparent, customer } \\
\text { first, trusted application }\end{array}$ \\
Re-use intention & $\begin{array}{l}\text { Intention to continue to re-use, intention to use as often as } \\
\text { possible, intention to recommend to others to use }\end{array}$
\end{tabular}




\section{RESULTS}

Ex-legacy Bank Syariah Mandiri dominated respondents at 83.57 percent; the majority of the education level in this study was 71.43 percent with a bachelor's degree. The results showed that private employees dominated the respondents' occupation by 90 percent and earned Rp. 5,000,000 to Rp. 10,000,000 is the largest, namely 37.86 percent, the largest amount of monthly savings of respondents is Rp. 500,000 to Rp. 1,000,000 $(31.79 \%), 37.86$ percent of the respondents are domiciled in the Banjarmasin region.

\section{The overall model fit test}

Evaluation of the level of fit of the model is carried out to determine the level of suitability of the original data to the model that has been designed based on the hypothesis that was built, as follows in Table 2.

Table 2. The results of the overall model fit test

\begin{tabular}{|c|c|c|c|c|}
\hline No. & GoF & Criteria & Result & Conclusion \\
\hline $\mathbf{A}$ & Absolut Match Size & & & \\
\hline 1 & $\begin{array}{l}\text { Root Mean Square } \\
\text { Residual (RMR) }\end{array}$ & $\begin{array}{l}\text { Standardized RMR } \leq 0,05 \text { : } \\
\text { good fit }\end{array}$ & 0,024 & good fit \\
\hline 2 & $\begin{array}{l}\text { Root Mean Square Error } \\
\text { of Approximation } \\
\text { (RMSEA) }\end{array}$ & $\begin{array}{l}\text { RMSEA } \leq 0,08 \text { is good fit, } \\
\text { RMSEA }<0,05 \text { is close fit }\end{array}$ & 0,091 & marginal fit \\
\hline 3 & $\begin{array}{l}\text { The goodness of Fit Index } \\
\text { (GFI) }\end{array}$ & $\begin{array}{l}\text { GFI } \geq 0,90 \text { : good fit } \\
0,80 \leq \text { GFI }<0,90 \text { : marginal } \\
\text { fit, }\end{array}$ & 0,8 & marginal fit \\
\hline B & Incremental Fit Size & & & \\
\hline 4 & Normed Fit Index (NFI) & $\begin{array}{l}\text { NFI } \geq 0,90: \text { good fit; } 0,80 \leq \\
\text { NFI < 0,90: marginal fit }\end{array}$ & 0,98 & good fit \\
\hline 5 & $\begin{array}{l}\text { Comparative Fit Index } \\
\text { (CFI) }\end{array}$ & $\begin{array}{l}\text { CFI } \geq 0,90 \text { : good fit; } 0,80 \leq \\
\text { CFI < 0,90: marginal fit }\end{array}$ & 0,98 & good fit \\
\hline 6 & Relative Fit Index (RFI) & $\begin{array}{l}\text { CFI } \geq 0,90 \text { : good fit; } 0,80 \leq \\
\text { CFI < 0,90: marginal fit }\end{array}$ & 0,97 & good fit \\
\hline 7 & $\begin{array}{l}\text { Adjusted Goodness of Fit } \\
\text { Index (AGFI) }\end{array}$ & $\begin{array}{l}\text { AGFI } \geq 0,90 \text { : good fit; } 0,80 \leq \\
\text { AGFI < } 0,90 \text { : marginal fit }\end{array}$ & 0,75 & marginal fit \\
\hline
\end{tabular}

Based on Table 2, it can be seen that the indicators of each type of measure have been represented and are in good fit.

\section{Validity Test Results}

Indicator variable to be valid if it has a Standardize Loading Factor (SLF) value greater than the tolerable loading factor limit, which is $\geq 0.5$ and has a $t$-value above 1.96 . The loading factor value is a coefficient that can show how much the relative contribution of each attribute (indicator variable) in forming exogenous latent variables. The validity test results of all indicators were declared valid.

Table 3. Validity Test Result

\begin{tabular}{ccccc}
\hline Variable & Indicator & Loading factor & t-count & Information \\
\hline Benefit Offered & $\mathrm{BO} 1$ & 0,53 & 16,46 & Valid \\
& $\mathrm{BO} 2$ & 0,60 & 16,65 & Valid \\
& $\mathrm{BO} 3$ & 0,61 & 15,05 & Valid \\
& $\mathrm{BO} 4$ & 0,61 & 16,88 & Valid \\
\hline
\end{tabular}




\begin{tabular}{lcrrc}
\hline \multicolumn{1}{c}{ Variable } & Indicator & Loading factor & t-count & Information \\
\hline Benefit Offered & BO5 & 0,61 & 15,44 & Valid \\
& BO6 & 0,57 & 17,91 & Valid \\
& BO7 & 0,50 & 16,49 & Valid \\
\hline Customer Experience & CX1 & 0,58 & 16,99 & Valid \\
& CX2 & 0,66 & 17,90 & Valid \\
& CX3 & 0,77 & 15,38 & Valid \\
& CX4 & 0,60 & 15,33 & Valid \\
& CX5 & 0,63 & 17,51 & Valid \\
\hline Satisfaction & CS1 & 0,59 & - & Valid \\
& CS2 & 0,63 & 21,38 & Valid \\
& CS3 & 0,63 & 19,23 & Valid \\
& CS4 & 0,62 & 22,33 & Valid \\
& CS5 & 0,59 & 21,37 & Valid \\
\hline Trust & TR1 & 0,61 & - & Valid \\
& TR2 & 0,64 & 25,92 & Valid \\
& TR3 & 0,64 & 23,54 & Valid \\
& TR4 & 0,64 & 25,03 & Valid \\
& TR5 & 0,68 & 25,93 & Valid \\
\hline Re-use intention & RI1 & 0,68 & - & Valid \\
& RI2 & 0,71 & 27,78 & Valid \\
& RI3 & 0,59 & 19,47 & Valid \\
\hline
\end{tabular}

\section{Reliability Test Results}

The variable is reliable if it meets two measurements: Variance Extracted (VE) and Construct Reliability (CR). The latent construct can be said to be reliable if the minimum value of $\mathrm{VE}$ is 0.5 and $\mathrm{CR}$ is 0.7 . The results showed that all variables were declared reliable because the VE value was 0.74 greater than 0.5 , and the $\mathrm{CR}$ value was 0.99 , greater than 0.7 (Table 4).

Table 4. Reliability Test Result

\begin{tabular}{|c|c|c|}
\hline Variable & VE & $\mathrm{CR}$ \\
\hline Benefit Offered & 0,74 & 0,99 \\
\hline Customer experience & 0,74 & 0,99 \\
\hline Satisfaction & 0,74 & 0,99 \\
\hline Trust & 0,74 & 0,99 \\
\hline Re-use intention & 0,74 & 0,99 \\
\hline
\end{tabular}

\section{Contribution of Indicators to Latent Variables}

The benefit offered variable has seven indicators. Based on the results of SEM analysis, indicators of completeness of spiritual features, completeness of social features, and reliability of mobile banking application services have the largest contribution with a loading factor value of 0.61 .

The customer experience variable consists of five indicators. The results of the SEM calculation show that think (CX3) has the largest contribution with a loading factor of 
0.77. This shows that attractive promo indicators are indicators that best reflect customer experience variables. In addition, the selection of these indicators also means that attractive promos will increase mobile banking re-use.

The satisfaction variable consists of five indicators. Indicators of a good relationship and fair treatment have the greatest contribution with a loading factor of 0.63 . This means that satisfaction and fairness in business dealings are factors that can be considered for improvement. This is because these indicators best describe the satisfaction variable.

The trust variable consists of five indicators. Respondents chose trusted applications as the largest contributor with a loading factor of 0.68 . The re-use intention variable has three indicators; the largest contribution value of the respondent's choice is the intention to use it as often as possible with a loading factor of 0.71 . This means that the indicator of intention to use as often as possible best describes the variable of re-use intention.

\section{HYPOTHESIS}

Based on the empirical study model that has been proposed in this study, further hypothesis testing can be carried out through testing the path coefficient and $t$-count on the structural equation model. If the path coefficient value is more than 0.05 with a $t$ count value of more than 1.96, then the influence between variables is included in the significant category. Conversely, if the path coefficient value is less than 0.05 with a $t$ count value less than 1.96, then it is included in the insignificant category. The estimation results of the SEM model based on the direct effect are presented in Table 5.

Table 5. Hypothesis Testing Table

\begin{tabular}{|c|c|c|c|c|c|}
\hline & \multicolumn{2}{|c|}{ Hypothesis } & \multirow{2}{*}{$\begin{array}{l}\begin{array}{l}\text { Path } \\
\text { Coefficient }\end{array} \\
0,33 \\
\end{array}$} & \multirow{2}{*}{$\begin{array}{l}\text { t-value } \\
6,20\end{array}$} & \multirow{2}{*}{$\begin{array}{c}\text { Result } \\
\text { Significant }\end{array}$} \\
\hline $\begin{array}{l}\text { H1 : Benefit } \\
\text { Offered (BO) }\end{array}$ & $\Rightarrow$ & Satisfaction (CS) & & & \\
\hline $\begin{array}{l}\mathrm{H} 2 \text { : Customer } \\
\text { Experience }(\mathrm{CX})\end{array}$ & $\Rightarrow$ & Satisfaction (CS) & 0,67 & 10,91 & Significant \\
\hline $\begin{array}{l}\text { H3 : Satisfaction } \\
\text { (CS) }\end{array}$ & $\Rightarrow$ & Trust (TR) & 0,93 & 19,28 & Significant \\
\hline H4 : Trust (TR) & $\Rightarrow$ & Re-use intention (RI) & 0,68 & 7,13 & Significant \\
\hline $\begin{array}{l}\text { H5 : Satisfaction } \\
\text { (CS) }\end{array}$ & $\Rightarrow$ & Re-use intention (RI) & 0,28 & 2,99 & Significant \\
\hline
\end{tabular}

The Effect of benefits Offered on Satisfaction

The benefit offered has a significant effect on satisfaction because it has a $t$-value of more than 1.96. The t-value obtained is 6.20 , which means the direction is positive. That is, the better the benefits offered the higher satisfaction. There are seven indicators that build the benefit offered, and the indicators that contribute significantly are the completeness of spiritual features (BO3), completeness of social features (BO4), and reliability of mobile banking application services (BO5) with a loading factor of 0.61 and a $\mathrm{t}$-value of more than 1,96. Thus, hypothesis H1 in this study is proven and accepted. 
This finding is in line with the situation in the field. The BSI mobile banking application has unique characteristics compared to other bank applications. The BSI mobile banking application has spiritual features such as prayer schedules, juzamma, Asmaul Husna, wisdom, and a qurban calculator. In addition, customers who wish to share with others can do so via BSI mobile banking such as zakat, infaq, waqf, and shodaqoh; the collected funds will be managed by a professional, experienced Laznas BSI institution. Of course, a reliable mobile banking application that can process every transaction quickly is what customers want. If the application is reliable, customers will be satisfied with BSI's mobile banking services.

The results of this study are supported by Medhi et al.(2009), which states that the benefit offered innovation built on the mobile banking application will increase customer satisfaction, increase profits and produce positive things. Anene and Okeji (2021) argue that mobile banking applications' reliability, including speed of money transfers, fast responses, guaranteed security systems, and can be done anywhere, will increase customer satisfaction. This is because customers feel the application is reliable. If the benefits offered by mobile banking are good, it will have a significant effect on customer satisfaction and vice versa. These results are in line with research conducted by Momeni et al. (2013) that states that the benefits offered, consisting of website design, transaction speed, security, and service, will significantly affect customer satisfaction.

The benefit offered has a significant effect on satisfaction because it has a $t$-value of more than 1.96. The $t$-value obtained is 6.20 , which means that the direction is positive. Thus, hypothesis $\mathrm{H}_{1}$ in this study is proven and accepted. Customer experience significantly affects satisfaction because it has a $t$-value of 10.91 or greater than the reference 1.96. Thus, the $\mathrm{H}_{2}$ hypothesis is proven and accepted in this study. Satisfaction has a significant effect on trust because it has a $t$-value of more than 1.96, which is 19.28. Thus, hypothesis $\mathrm{H}_{3}$ is proven and can be accepted. Trust has a significant effect on re-use intention because it has a $t$-value of more than 1.96. The $t$-value obtained is 7.13 , which means that the direction is positive. Thus, hypothesis $\mathrm{H}_{4}$ in this study is proven and accepted. Satisfaction has a significant effect on re-use intention because it has a $t$-value of more than 1.96. The $\mathrm{t}$-value obtained is 2.99 . Thus, hypothesis $\mathrm{H}_{5}$ in this study is accepted and proven.

\section{The Effect of Customer Experience on Satisfaction}

Customer experience has a significant effect on satisfaction because it has a $t$-value of 10.91 or greater than the reference of 1.96 . The results of this study indicate the influence of customer experience on satisfaction. Five indicators build customer experience. The indicator that contributes significantly is think (CX3), with a loading factor of 0.77 and a t-value of 15.38. This means that overall, consumers are satisfied with the promos offered by BSI mobile banking and in accordance with consumer expectations. Thus, hypothesis $\mathrm{H} 2$ is proven and accepted in this study.

Customer experience when shopping online conducting via mobile will affect customer satisfaction (San-Martín et al. 2016). Then, Pei et al.(2020) stated that customer experience, which includes customer service, both online and physical, shopping environment, product experience, and shopping procedures, positively affects customer satisfaction. These results are also similar to the research conducted by Vakulenko et al.(2019) that customer experience is the key that influences customer satisfaction today. In addition, the results show that customer satisfaction is an indicator of a successful 
product having long-term sustainable competitiveness. This result is convincing that customer experience is an essential source of sustainable competitive advantage for companies through mobile banking differentiation strategies.

\section{The effect of satisfaction on trust}

In this study, satisfaction significantly affects trust because it has a $t$-value of more than 1.96, which is 19.28. These results prove that there is an effect of satisfaction on customer trust. Satisfaction has five indicators that build it. Indicators that contribute significantly are good relationship (CS2) and fair treatment (CS3), with a loading factor of 0.63 and a $t$-value of more than 1.96. This means that customer satisfaction is established because of a good relationship and a fair attitude, making customers believe in BSI mobile banking. Thus, hypothesis $\mathrm{H} 3$ is proven and can be accepted. These results are in accordance with the conditions in the field that when BSI mobile banking customers are satisfied, it will lead to trust, which increases the re-use of mobile banking.

Fang et al. (2014) state that satisfaction significantly influences satisfaction and online purchase trust. Consistently, Walter et al.(2000), Madjid (2013), and (Simanjuntak et al. 2020a) found that customer satisfaction has a significant effect on trust. Good mobile banking satisfaction will increase customer confidence to continue to use it again. However, on the other hand, if customer satisfaction decreases, the re-use of mobile banking will decrease as well.

\section{The effect of trust on re-use intention}

Trust has a significant effect on re-use intention because it has a $t$-value of more than 1.96. The $t$-value obtained is 7.13 , which means the direction is positive. That is, the better the trust will increase the re-use intention. Five indicators build trust with indicators that contribute significantly are trusted applications (TR5) with a loading factor value of 0.68 and a $t$-value of 25.93 . Thus, hypothesis $\mathrm{H}_{4}$ in this study is proven and accepted.

The results of this study are in accordance with the research of Masri et al.(2021), which states that customer trust in online purchases has a high direct effect on purchase intention and re-use. Astarina et al.(2017) also state the same thing, that trust is able to be a perfect mediator that has a positive influence on online purchase intentions. Then Hong \& Cho (2011) show that online shopping requires trust, and trust in online shopping will affect repeat purchases online

\section{The effect of satisfaction on re-use intention}

Satisfaction has a significant effect on re-use intention because it has a $t$-value of more than 1.96. The $t$-value obtained is 2.99 . That is, good satisfaction will increase re-use intention. Three indicators build re-use intention; an indicator that contributes significantly is the intention to use frequently (RI2) with a loading factor of 0.71 and a $t$ value of 27.78 . Thus, hypothesis $\mathrm{H}_{5}$ in this study is accepted and proven.

The results of this study are in line with the study of He et al.(2008), which informs that high consumer satisfaction will increase the intention to use or re-purchase so that company profitability will increase simultaneously. Nilsson and Wall (2017) also confirm the relationship between satisfaction and customer re-purchase intentions. Likewise, Qureshi et al. (2009) found that satisfaction with repeat purchases will increase the intention to re-purchase online; this needs to be maintained and evaluated continuously. 


\section{DISCUSSION}

Indicators of the benefit offered variable that have the most significant contribution are completeness of spiritual features, completeness of social features, and reliability of mobile banking application services. Therefore, BSI is suitable for developing spiritual and social elements in its mobile banking application. However, innovation and collaboration are needed to make the features more complete. In addition, the reliability of the application needs to be improved so that customer mobile banking access can be smooth at any time.

Customer experience has five indicators; the enormous contribution is thought related to promotions in mobile banking. BSI needs to carry out promotions on mobile banking on an ongoing basis for the right segment and time. For example, customers like to conduct a transaction with Shopee Pay; promotions can be done by cashback when topping up Shopee Pay via BSI mobile banking. This is important to attract customers to re-use their mobile banking.

Indicators of satisfaction that get the highest contribution are good relationships and fair treatment. It means that BSI customers must make their mobile banking a customer mainstay so that satisfaction increases. In addition, BSI mobile banking must act fairly, both in terms of promotions, information, and features.

The indicator of the trust that has the greatest contribution is a trusted application, meaning that BSI has been trusted by customers as experts and experienced in mobile banking. Of course, this must be maintained and improved, for example, by socializing on social media (Instagram, YouTube, Facebook, etc.) so that the BSI mobile banking brand image can be embedded and will lead to customer trust.

Finally, based on the research results, the indicator of re-use intention that has a dominant contribution is the intention to use it as often as possible. This means that if benefits offered, customer experience, satisfaction, and trust can be improved, the re-use of mobile banking will also increase. Increased use means that the fee base will increase, which will impact BSI's bottom line, namely the growth of company profits.

\section{CONCLUSION, LIMITATIONS, AND SUGGESTIONS}

\section{Conclusion}

This study concludes that the benefits offered and customer experience have a positive and significant effect on satisfaction. Good benefits offered can increase customer satisfaction; the benefits offered include improving financial features, social features, and spiritual features characteristic of BSI. The level of security and speed of mobile banking is also the main attraction of increasing satisfaction. In addition, customer experience will also increase customer satisfaction through modern mobile banking designs, attractive promos, and Islamic services that are quite complete for customers.

The managerial implication that can be implemented in the company is to maintain deeper Islamic features so that customers can be even better in carrying out their worship rituals. According to the results of SEM, the indicator of the benefit offered variable that has the largest contribution is the completeness of spiritual features and the completeness of social features with a loading factor of 0.61 . In addition, social features also need to be 
maintained in order to be different from other mobile banking. Customers not only think about themselves but also share with others managed by professional and targeted institutions.

Improving network quality and capacity is the main thing to access BSI mobile banking anytime and anywhere. In addition, BSI mobile must also continue to innovate against changing trends both in terms of features and services consistently to serve customers' growing needs.

\section{Limitation and suggestions}

This research was only conducted on the BSI mobile banking application. The results might be different if the research was conducted on other bank's mobile banking. Therefore, managerial conclusions and implementations may not be suitable for implementation in other banks. In addition, the determination of the sample using nonprobability sampling whose results can only be concluded on the research sample cannot be generalized to the population.

Further research can be carried out when BSI has implemented a single system, in which all former legacy customers of Bank Syariah Mandiri (BSM), BNI Syariah (BNIS), and BRI Syariah (BRIS) have used the same core banking. In addition, we can consider research using other variables that can increase the re-use of mobile banking, such as eservice quality and electronic word of mouth (e-WOM). The addition of these variables is to get a broader view of the re-use of mobile banking.

\section{REFERENCES}

Adzhani NK, Hartoyo, Simanjuntak M. 2021. Analysis of Satisfaction and Loyalty with the Customer Experience Approach. International Journal and Review. 8(3) pp:391402.

Ajzen I. 1991. The theory of planned behavior. Organ Behav Hum Decis Process. 50(2):179211. https://doi.org/10.1016/0749-5978(91)90020-T.

Anene IA, Okeji CC. 2021. Awareness, Acceptance, and Usage of Mobile Banking Services by Academic Librarians in Nigeria. Libr Philos Pract.

Arief A, Simanjuntak M, Kirbrandoko. 2019. Analysis of Factors Affecting the Satisfaction and Loyalty of the Use of Cargo Services: a Case Study of Pt. Bex. Russ J Agric SocioEconomic Sci. 87(3):276-283. https:/ / doi.org/10.18551/rjoas.2019-03.32.

Arwani M, Taufik, Masluri. 2011. Peran Karakteristik Individu Sebagai Moderator Pengaruh Kepuasan, Kepercayaan dan Komitmen Terhadap Loyalitas (Studi pada Nasabah Bank Syariah di Kabupaten Kudus). J Sos dan Budaya. 4(2):159-170.

Astarina IGA, Giantari IGAK, Yasa NNK. 2017. Peran Kepercayaan Memediasi Pengaruh Pengalaman Terhadap Niat Menggunakan Kembali Jasa Go-Jek Di Kota Denpasar. Manaj Unud, . 6(5):2308-2334.

Benedicktus RL, Brady MK, Darke PR, Voorhees CM. 2010. Conveying Trustworthiness to Online Consumers: Reactions to Consensus, Physical Store Presence, Brand Familiarity, and Generalized Suspicion. J Retail. 86(4):322-335. https:// doi.org/10.1016/j.jretai.2010.04.002. 
Bua H. 2009. Pengaruh Kompetensi Agen Terhadap Kepercayaan Konsumen Pada Perusahaan Asuransi Gabungan Tabungan Dan Resiko Di Sulawesi Tenggara. J Ekon dan Bisnis Airlangga (J E $B \quad$ A). 19(1):56-75. https:// doi.org/10.20473/jeba.V19I12009.4256.

Casaló L V., Flavián C, Guinalíu M. 2008. The role of satisfaction and website usability in developing customer loyalty and positive word-of-mouth in the e-banking services. Int J Bank Mark. 26(6):399-417. https:/ / doi.org/10.1108/02652320810902433.

Danesh SN, Ahmadi Nasab S, Choon Ling K. 2012. The Study of Customer Satisfaction, Customer Trust and Switching Barriers on Customer Retention in Malaysia $\begin{array}{lllll}\text { Hypermarkets. Int } J \text { Bus } & \text { Manag. 141-150. }\end{array}$ https:// doi.org/10.5539/ijbm.v7n7p141.

Dholakia RR, Zhao M. 2010. Dholakia \& Zhao - online store attributes on customer satisfaction - International Journal of Retail and Distribution Management. 38(7):11. https://10.1108/09590551011052098

Ebrahimi DMR, Tootoonkavan S. 2014. Investigating the Effect of Perceived Service Quality, Perceived Value, Brand Image, Trust, Customer Satisfaction on Repurchase Intention and Recommendation to Other Case study: LG Company. European Journal of Business and Management. 6(34):181-187.

Fang Y, Qureshi I, Sun H, McCole P, Ramsey E, Lim KH. 2014. Trust, satisfaction, and online re-purchase intention: The moderating role of perceived effectiveness of ecommerce institutional mechanisms. MIS Q Manag Inf Syst. 38(2):407-427. https://doi.org/10.25300/MISQ/2014/38.2.04.

Fang YH, Chiu CM, Wang ETG. 2011. Understanding customers' satisfaction and repurchase intentions: An integration of IS success model, trust, and justice. Internet Res. 21(4):479-503. https:// doi.org/10.1108/10662241111158335.

Fikri A, Nurmalina R, Najib M, Simanjuntak M. 2019. The Effect of Reputation on Online Repurchase Intention of Fruits/Vegetables in Indonesia With Emotional and Perceived Risk as Antecedent: Based on The Stimulus-Organism-Response Model. Jurnal Manajemen dan Agribisnis. 16(2):111-122. https:// doi.org/10.17358/jma.16.2.111.

Giannakos MN, Pateli AG, Pappas IO. 2011. Identifying the Direct Effect of Experience and the Moderating Effect of Satisfaction in the Greek Online Market. International Journal E-Services Mobile Application. 3(2):39-58. https:// doi.org/10.4018/jesma.2011040103.

Giantari IGAK, Zain D, Rahayu M, Solimun. 2013. The role of perceived behavioral control and trust as a mediator of experience on online purchasing intentions relationship a study on youths in Denpasar city (Indonesia ). International Journal Business and Management Invention. 2(1):30-38.

Hayashi F, Toh YL. 2020. Mobile Banking Use and Consumer Readiness to Benefit from Faster Payments. Federal Reserve Bank Kansas City. Vol.0(1), pp. 1-5. https:// doi.org/10.18651/ER/v105n1HayashiToh

He Y, Chan LK, Tse SK. 2008. From consumer satisfaction to re-purchase intention: The 
role of price tolerance in a competitive service market. Total Quality Management Business Excellent. 19(9):949-961. https:/ / doi.org/10.1080/14783360802224628.

Hong IB, Cho H. 2011. The impact of consumer trust on attitudinal loyalty and purchase intentions in B2C e-marketplaces: Intermediary trust vs. seller trust. Int J Inf Manage. 31(5):469-479. https:// doi.org/10.1016/j.ijinfomgt.2011.02.001.

Hult GTM, Sharma PN, Morgeson F V., Zhang Y. 2019. Antecedents and Consequences of Customer Satisfaction: Do They Differ Across Online and Offline Purchases? Journal Retail. 95(1):10-23. https:/ / doi.org/10.1016/j.jretai.2018.10.003.

Kalinić Z, Marinković V, Djordjevic A, Liebana-Cabanillas F. 2020. What drives customer satisfaction and word of mouth in mobile commerce services? A UTAUT2-based analytical approach. Journal of Enterprise Information Management. 33(1):71-94. https:// doi.org/10.1108/JEIM-05-2019-0136.

Kim DJ, Ferrin DL, Rao HR. 2009. Trust And Satisfaction, Two Stepping Stones For Successful E-Commerce Relationships: A Longitudinal Exploration. Information System Research. 20:237-257. https:/ / doi.org/10.1287/isre.1080.0188.

Lee H, Harindranath G, Oh S, Kim DJ. 2015. Provision of mobile banking services from an actor-network perspective: Implications for convergence and standardization. Technological Forecast and Social Change. 90 PB:551-561. https://doi.org/10.1016/j.techfore.2014.02.007.

Liébana-Cabanillas F, Muñoz-Leiva F, Sánchez-Fernández J, Viedma-del Jesús MI. 2016. The moderating effect of user experience on satisfaction with electronic banking: empirical evidence from the Spanish case. Inf Syst E-bus Manag. 14(1):141-165. https:// doi.org/10.1007/s10257-015-0277-4.

Liu Y, Tang X. 2018. The effects of online trust-building mechanisms on trust and repurchase intentions: An empirical study on eBay. Inf Technol People. 31(3):666-687. https:// doi.org/10.1108/ITP-10-2016-0242.

Madjid R. 2013. Customer Trust as Relationship Mediation Between Customer Satisfaction and Loyalty At Bank Rakyat Indonesia ( BRI ) Southeast Sulawesi. International Journal of Engineering and Science. 2(5):48-60.

Mantala, Firdaus R dan MR. 2016. Pengaruh Customer Experience Terhadap Customer Satisfaction pada Pengguna Smartphone Android (Studi pada Mahasiswa Politeknik Negeri Banjarmasin). Jurnal Wawasan Manajemenj. 4(2):153-164. https://dx.doi.org/10.20527/jwm.v4i2.86

Masri NW, Ruangkanjanases A, Chen SC. 2021. The effects of product monetary value, product evaluation cost, and customer enjoyment on customer intention to purchase and re-use vendors: Institutional trust-based mechanisms. Sustain. 13(1):120. https://doi.org/10.3390/su13010172.

McCole P, Ramsey E, Kincaid A, Fang Y, LI H. 2019. The role of structural assurance on previous satisfaction, trust and continuance intention: The case of online betting. Inf Technol People. 32(4):781-801. https:/ / doi.org/10.1108/ITP-08-2017-0274.

Medhi I, Ratan A, Toyama K. 2009. Internationalization, Design and Global Development. 5623 July 2009:29-38. https:/ / doi.org10.1007/978-3-642-02767-3. 
Momeni M, Kheiry B, Dashtipour M. 2013. Analysis the Effects of Electronic Banking on Customer Satisfaction and Loyalty (Case Study: Selected Branches of Melli Bank in Tehran). Interdiscip J Contemp Res Bus. 4(12):230. http://journalarchieves31.webs.com/230-241.pdf.

Mulyono SH, Djatmiko T. 2018. Pengaruh Customer Experience Terhadap Customer Satisfaction di Tokopedia. e-Proceeding Manag. 5(2):1843-1848.

Nangi IY, Sukaatmadja IPG. 2015. Pengaruh Aplikasi Tam Dan Kepercayaan Terhadap Minat Mahasiswa Membeli Ulang Menggunakan E-Commerce Dalam Pembelian Produk Pakaian Dan Aksesoris. E-Jurnal Manaj Unud. 4(7):1-14.

Nasermoadeli A, Ling KC, Maghnati F. 2013. Evaluating the Impacts of Customer Experience on Purchase Intention. Int J Bus Manag. 8(6). https:// doi.org/10.5539/ijbm.v8n6p128.

Nasution DAD, Erlina E, Muda I. 2020. Dampak Pandemi COVID-19 terhadap Perekonomian Indonesia. Benefita. 5(2):212. https:// doi.org/10.22216/jbe.v5i2.5313.

Nilsson J, Wall O. 2017. Online customer experience, satisfaction, and re-purchase intention for online clothing retailing. Univ Gothenbg, Sch Bus, Econ Law, Gothenburg, Sweden., siap terbit.

Norhermaya YA, Soesanto HS. 2016. Analisis Pengaruh Kepuasan Pelanggan Terhadap Kepercayaan Dan Loyalitas Pelanggan Untuk Meningkatkan Minat Beli Ulang (Studi Pada Online Store Lazada.Co.Id). Diponegoro J Manag. 5(2007):1-13. https:/ / ejournal3.undip.ac.id/index.php/djom/article/view/14952.

Oliver RL, DeSarbo WS. 1988. Response Determinants in Satisfaction Judgments. Journal pf Consumer Research. 14(4):495. https:/ / doi.org/10.1086/209131

Pebriani WV, Sumarwan U, Simanjuntak M. 2018. The Effect of Lifestyle, Perception, Satisfaction, and Preference on The Online Re-purchase Intention. Independent Journal of Management and Production. 9(2):545. https:// doi.org/10.14807/ijmp.v9i2.690.

Pei XL, Guo JN, Wu TJ, Zhou WX, Yeh SP. 2020. Does the effect of customer experience on customer satisfaction create a sustainable competitive advantage? A comparative study of different shopping situations. Sustain. 12(18):1-20. https:// doi.org/10.3390/SU12187436.

Prayoga IMS, Yasa NNK, Wardana M. 2015. Relational Benefit, Kepuasan, Dan Loyalitas Pelanggan Pada Bengkel Pt Honda Dewata Motor. J Manaj dan Kewirausahaan (Journal Manag Entrep.17(1):11-20. https:/ / doi..org/10.9744/jmk.17.1.11-20.

Püschel J, Mazzon JA, Hernandez JMC. 2010. Mobile banking: Proposition of an integrated adoption intention framework. International Journal of Bank Marketing. 28(5):389-409. https:// doi.org/10.1108/02652321011064908.

Ranaweera C, Prabhu J. 2003. The influence of satisfaction, trust, and switching barriers on customer retention in a continuous purchasing setting. International Journal Service Industry Management. 14(3-4):374-395. https://doi.org/10.1108/09564230310489231. 
Rini SE. 2019. Menciptakan Pengalaman Konsumen dengan Experiential Marketing. J Bisnis Dan Kajian Strategi Manaemenj. 1(1):15-20. https:// doi.org/10.35308/jbkan.v1i1.914.

Sagib GK, Zapan B. 2014. Bangladeshi mobile banking service quality and customer satisfaction and loyalty. Manag Mark. 9(3):331-346.

Saidani B, Lusiana LM, Aditya S. 2019. Analisis Pengaruh Kualitas Website dan Kepercayaan Terhadap Kepuasaan Pelanggan dalam Membentuk Minat Pembelian Ulang pada Pelanggan Shopee. Jurnal Riset Manajemen Sains Indonesia. 10(2):425-444.

Salim FK, Catherine. 2013. Pengaruh Customer Experience dan Kepercayaan Terhadap Kepuasan Konsumen di TX Travel Klampis. J Chem Inf Model. 01(01):1689-1699.

Sampaio CH, Ladeira WJ, Santini FDO. 2017. Apps for mobile banking and customer satisfaction: a cross-cultural study. Int J Bank Mark. 35(7):1131-1151. doi:10.1108/IJBM-09-2015-0146.

Samudro A, Sumarwan U, Simanjuntak M, Yusuf EZ. 2019. How Commitment, Satisfaction, and Cost Fluctuations Influence Customer Loyalty. Global Academy of Training \& Research. 4(2):115-125. https:/ / doi.org/10.35609/jmmr.2019.4.2(3).

Samudro A, Sumarwan U, Simanjuntak M, Yusuf EZ. 2020. Assessing the effects of perceived quality and perceived value on customer satisfaction. Manag Sci Lett. 10(5):1077-1084. https:/ / doi.org10.5267/j.msl.2019.11.001.

San-Martín S, Prodanova J, López Catalán B. 2016. What makes services customers say "buy it with a mobile phone"? Journal of Service Marketing. 30(6):601-614. https:/ / doi.org/10.1108/JSM-02-2015-0081.

Sidharta I, Suzanto B. 2015. Pengaruh Kepuasan Transaksi Online Shopping dan Kepercayaan Konsumen Terhadap Sikap Serta Perilaku Konsumen Pada ECommerce. Jurnal Ilmu dan Riset Manajemen. 1(7):23-26. http://jurnalmahasiswa.stiesia.ac.id/index.php/jirm/article/download/1753/176 3.

Simanjuntak M, Nur HR, Sartono B, Sabri MF. 2020a. A general structural equation model of the emotions and re-purchase intention in modern retail. Management Science Letter. 10(4):801-814. https:/ / doi.org/10.5267/j.msl.2019.10.017.

Simanjuntak M, Putri NE, Yuliati LN, Sabri MF. 2020b. Enhancing customer retention using customer relationship management approach in car loan business. Cogent Business and Management. 7(1). https:/ / doi.org/10.1080/23311975.2020.1738200.

Susanti V, Sumarwan U, Simanjuntak M, Yusuf EZ. 2019a. The Rational Factors of Perceived Quality and Perceived Value as the Drivers of Customer Satisfaction and Brand Loyalty. Jurnal Ilmu Administrasi dan Organisasi. 26(3). https:// doi.org/10.20476/jbb.v26i3.11121.

Susanti V, Sumarwan U, Simanjuntak M, Yusuf EZ. 2019b. Pengaruh Perceived Brand Quality, Perceived Value Dan Switching Cost Terhadap Customer Satisfaction Dan Brand Loyalty: Studi Pasar Industri Kimia Di Indonesia. Mix: Jurnal Ilmiah Manajemen. 9(2):282. https://doi.org/10.22441/mix.2019.v9i2.003. 
Tiana IM, Prihatiningrum RY, Rifani A. 2019. Pengaruh Benefits Offered Aplikasi Mobile Banking terhadap Kepuasan Nasabah, Kepercayaan, Loyalitas dan Positive Word Of Mouth (WOM). JABE (Journal of Applied Business and Economic. 5(4):351. https:// doi.org/10.30998/jabe.v5i4.4184.

Tran HTT, Corner J. 2016. The impact of communication channels on mobile banking adoption. International Journal of Bank Marketing. 34(1):78-109. https:// doi.org/10.1108/IJBM-06-2014-0073.

Vakulenko Y, Shams P, Hellström D, Hjort K. 2019. Online retail experience and customer satisfaction: the mediating role of last-mile delivery. The International Review of Retail, Distribution, and Consumer Research 29(3):306-320. https:// doi.org/10.1080/09593969.2019.1598466.

Verhoef PC, Lemon KN, Parasuraman A, Roggeveen A, Tsiros M, Schlesinger LA. 2009. Customer Experience Creation: Determinants, Dynamics and Management Strategies. Journal Retail. 85(1):31-41. https:// doi.org/10.1016/j.jretai.2008.11.001.

Walter A, Mueler T a., Helfert G. 2000. The Impact of Satisfaction, Trust, and Relationship Value on Commitment: Theoretical Considerations and Empirical Results. 16Th IMP Conf.

Yamali FR, Putri RN. 2020. Dampak Pandemi Covid-19 Terhadap Ekonomi Indonesia. Medcom,Id. 4(2):1. https:/ / doi.org/10.33087/ekonomis.v4i2.179.

Yuliati LN, Dradjat HA, Simanjuntak M. 2020. Online bike: Role of perceived technology, perceived risk, and institution-based trust on service usage via online trust. Cogent Business Management. 7(1):0-19. https:/ / doi.org/10.1080/23311975.2020.1798067.

Zhou L, Dai L, Zhang D. 2007. - a Critical Survey of Consumer Factors in Online Shopping. 8(1):41-62. 